\title{
INFORMATION SYSTEM DESIGN OF SHAHIRAH RAHMAWATI DENTIST'S PRACTICE BASED ON WEB AND SMS GATEWAY USING THE RATIONAL UNIFIED PROCESS METHODOLOGY
}

\author{
M.Hasim Siregar \\ Fakultas Teknik Program Studi Teknik Informatika, Universitas Islam Kuantan Singingi, Riau - Indonesia
}

\begin{tabular}{|c|c|}
\hline Article Info & ABSTRACT \\
\hline Article history: & $\begin{array}{l}\text { Dental practices is one of the services in the field of Health has already } \\
\text { managed independently so it is required to provide the best service to }\end{array}$ \\
\hline Received 23 May, 2021 & the society with good management. In good management, it does not \\
\hline Revised 17 June, 2021 & need to be done repeatedly, for example, nurses or employees check, \\
\hline Accepted 17 June, 2021 & $\begin{array}{l}\text { store, or search for medical records manually even though only on the } \\
\text { same variable. In the dental practice of Shahirah Rahmawati, }\end{array}$ \\
\hline Keywords: & $\begin{array}{l}\text { appointments are still made by telephone and recorded on paper so it } \\
\text { is less effective and less practical. The recording of dental medical }\end{array}$ \\
\hline Sistem & records and medicines are also done manually. So that why the \\
\hline RationalUnifiedProcess & research doing to design an information system using an object- \\
\hline SMSGateway & oriented approach. On the whole process, from input data, and \\
\hline Informasi & presentation of reports aims to make easy for users and to schedule \\
\hline UML & regular patient visits using SMS Gateway. \\
\hline
\end{tabular}

This is an open access article under the CC BY-SA license.

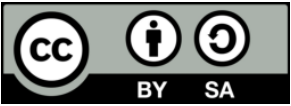

\section{Corresponding Author:}

\author{
M.Hasim Siregar \\ Fakultas Teknik Program Studi Teknik Informatika \\ Universitas Islam Kuantan Singingi \\ Riau - Indonesia \\ Email: hasyimsiregar92@gmail.com \\ (c) M.Hasim Siregar 2021
}

\section{Introduction}

The private practice dentists is currently growing rapidly, many people visit not only to check dental health but also to aesthetics or dental beauty. In carrying out management in private dentist, there are difference management from hospitals or polyclinics which have complex and structured management. The management requires recording and managing data effectively and does not waste the time. The practice must manage patients, medical records, drugs and finances and improve services to patients by using computerized system. It can increase the efficiency and performance of the process than manual processes which require much time and energy and the data search process is more difficult and takes longer [1]. If viewed from the environmental conditions, not all of the society have smartphone cellular devices can use internet, it is necessary to use SMS Gateway technology [2]. Many studies have been conducted on the use of Web-based Information Systems or 
Technology to support management/organizational performance. The system is a network of interconnected procedures, gathered together to carry out an activity or to complete a certain goal. Information is data has been processed into more meaningful and useful for the recipient to make the decision now and in the future [3]. So, the information system is collection and components in an organization related to the process of information flow. Computer-based, information systems also use computer hardware and software, networks, database management, and various other forms of information technology with the aim in converting data sources into various kinds of information needed by users [4]. In dental practice of Shahirah Rahmawati, many records were done manually on paper and are often a waste of time because nurses have to look for the patient's medical record file. The outpatient services can make a patient's medical record with data as the medical record, including: patient identity, date and time, history, diagnosis, treatment plan [5] and sometimes the archive is lost or torn, patients often forget to come back so the doctor/nurse calls the patient to come back and reschedule. It is necessary the application to ease it. It will be using sms gateway with the gammu application. Gammu is a technology service used in building application based on SMS gateway [6].

Based on various problems occured at dental practice of shahirah rahmawati from appointments to medical records and patient visit schedules, it is necessary to design a system can process patient data to record patient medical records and schedule reminders for patients. Applications made with web-based programming using PHP as the programming language and CodeIgniter as the framework and MySQL as database and Gammu as the SMS Gateway.

\section{Research Method}

\section{Data and Information Collection Method}

In obtaining information and data used in this research, the method used as follows:

1. Primary Data

This data was collected through interviews with the owner as well as dentists from the dental practice of Shahirah Rahmawati, the employee and the patients who can provide the information needed for the development of information systems.

2. Secondary Data

The data used are theoretical knowledge obtained from relevant reference journals and related books.

\section{System Development Method}

In developing the system, there are phases of system development in design of this dental practice information system using the RUP (Rational Unified Process) methodology. It is a software development approach was conducted iteratively, focused on architecture (architecture-centric), and use case driven. RUP is also one of the methodologies used in software development, especially object-oriented software activities model development using the Unified Modeling Language (UML) [7] The phases in RUP methodology [8] consist of:

1. Inception (beginning)

This phase focused on the process of business modelling and requirements system.

2. Elaboration (expansion/planning)

This phase focused on system architecture planning. This phase can detect the invention system and can detect its risk. This phase also can analyze and design the system, can implement it into prototype system and produces Lifecycle Architecture Milestones.

3. Construction (construction)

This phase focused on developing components and features of system and implementing and testing onto software in program code. This phase produces a software product as requirement of the Initial Operational Capability Milestone.

4. Transition

This phase focused on the deployment or installation of the system to produce a software to make the user understand how the maintenance and testing of the system. 


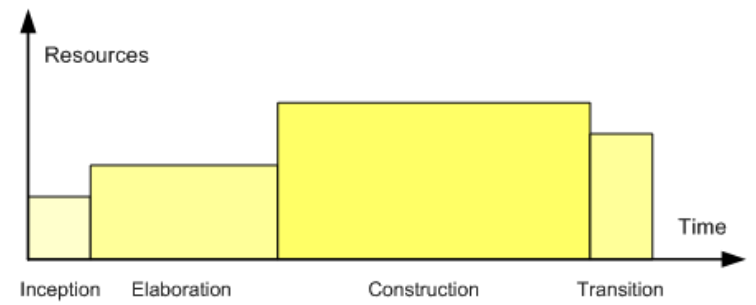

\section{Result and Discussion}

\subsection{Inception}

\subsubsection{Use Case Diagram}

Use Case Diagram is a model for behavior or flow of the information system to be made. The following is the figure of use case diagram of the dental practice information system of Shahirah Rahmawati as follows:

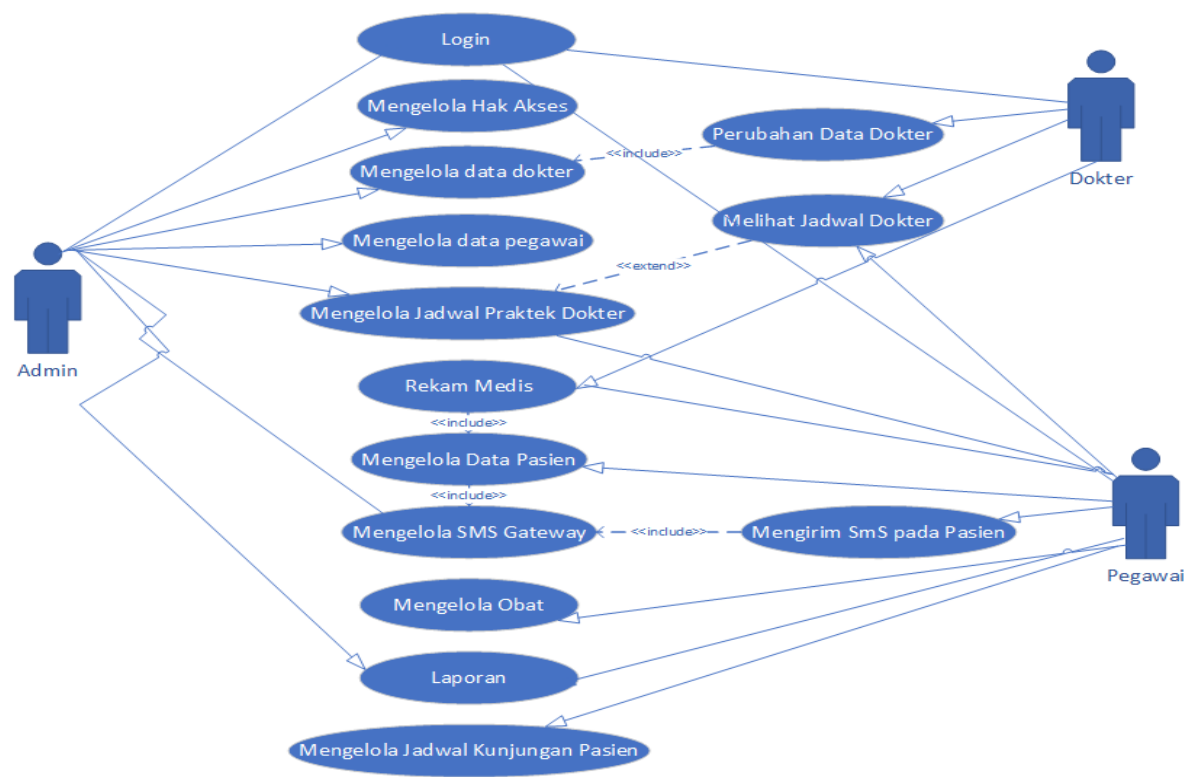

Figure 2. Use Case Diagram Sisfo of Shahirah Rahmawati Dentist

In Use Case Diagram above, it can be seen that there are 3 actors in accessing the system, such as: admin, doctor and employee. Admin can login, can manage access rights/users on the system, can manage doctor data, can manage employee data, can manage doctor's schedule, can manage sms gateway and can manage the reports. Doctor can login, can change the doctor's data, can see the doctor's schedule and can manage medical records. Then, employees can login, can see the doctor's schedule, can manage the doctor's schedule, can see medical records, can manage patient data, can send sms to patient, can manage patient visit schedules, and can make the reports.

\subsection{Elaboration (Perencanaan Arsitektur Sistem)}

\subsubsection{Activity Diagram}

Activity diagram is model for the behavior in Use Case and Objects based on the actors and functions. In this activity diagram there are 3 types of activity, they are: admin activity, doctor activity and employee activity. 


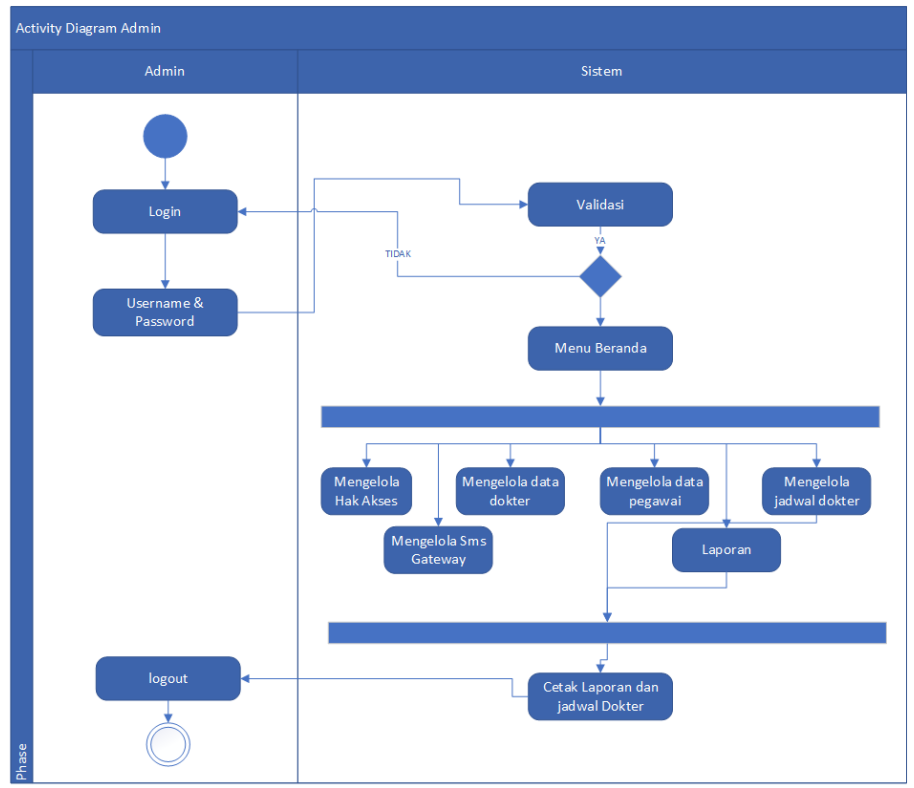

Figure 3. Admin Activity Diagram

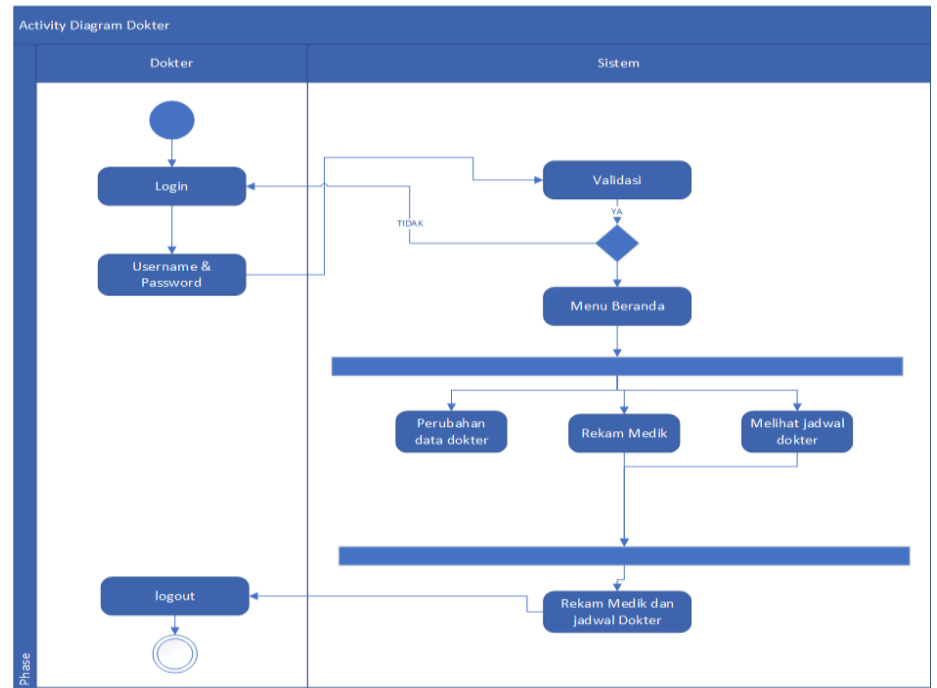

Figure 4. Dentist Activity Diagram 


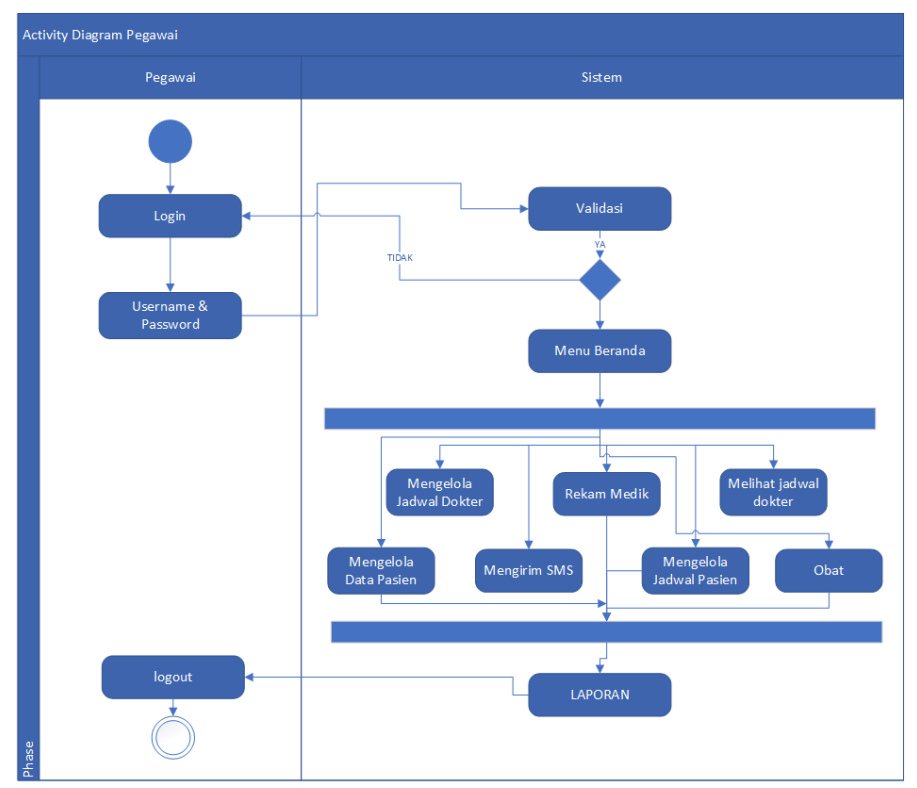

Figure 5. Employee Activity Diagram

\subsubsection{Class Diagram}

Class diagram is the relationship between classes and explains the details of each class in design model of a system and show the rules and responsibilities of the entities to determine the behavior of the system. A class diagram also show the attributes and operations of class and constraints related into the connected object. [10]

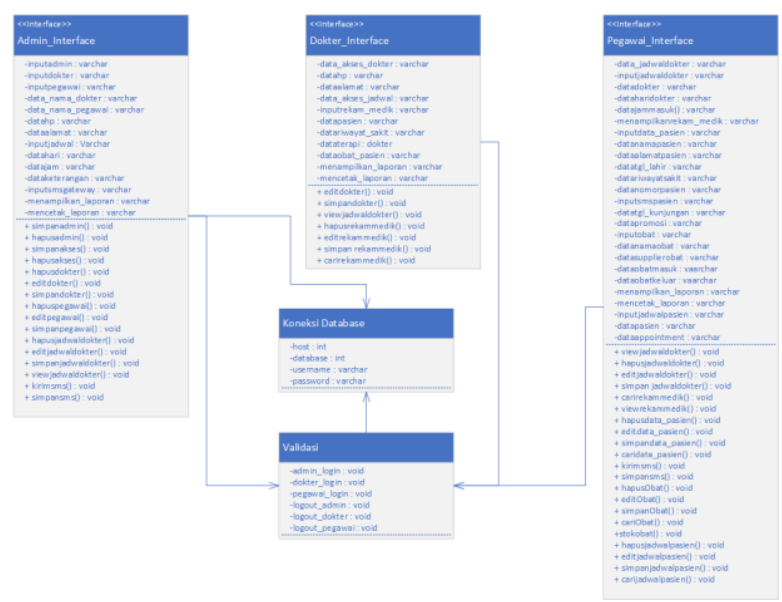

Figure 6. Class Diagram of Information Sytem

\subsubsection{Entity Relationship Diagram (ERD)}

The relationship diagram or Entity Relationship Diagram (ERD) is network model in describing the plan or arrangement of data stores from a high level separator system. This E-R is used to describe the relationship between data stores or data stores contained in the ERD. [11] 


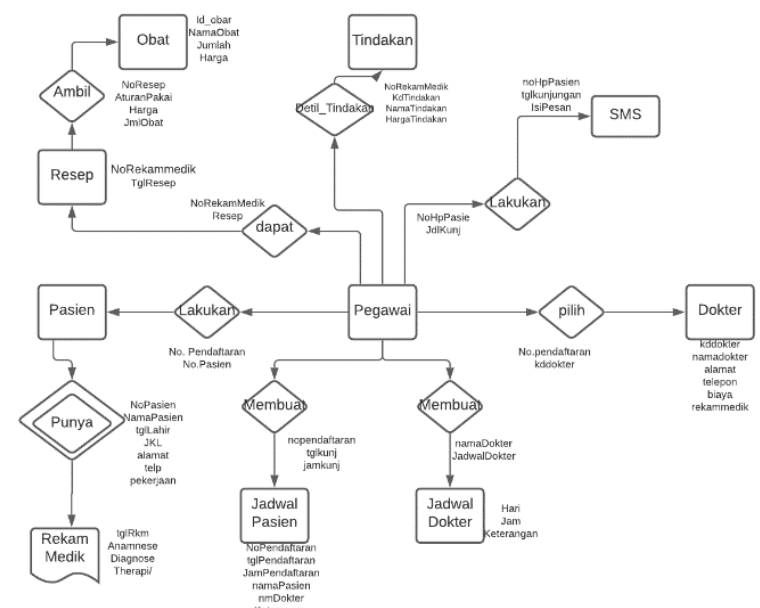

Figure 7. Entity Relationship Diagram (ERD) Information System

\subsubsection{Logical Record Structure (LRS)}

Logical Record Structures are collections of the structure records in table formed as a result of processing between entity sets [12].

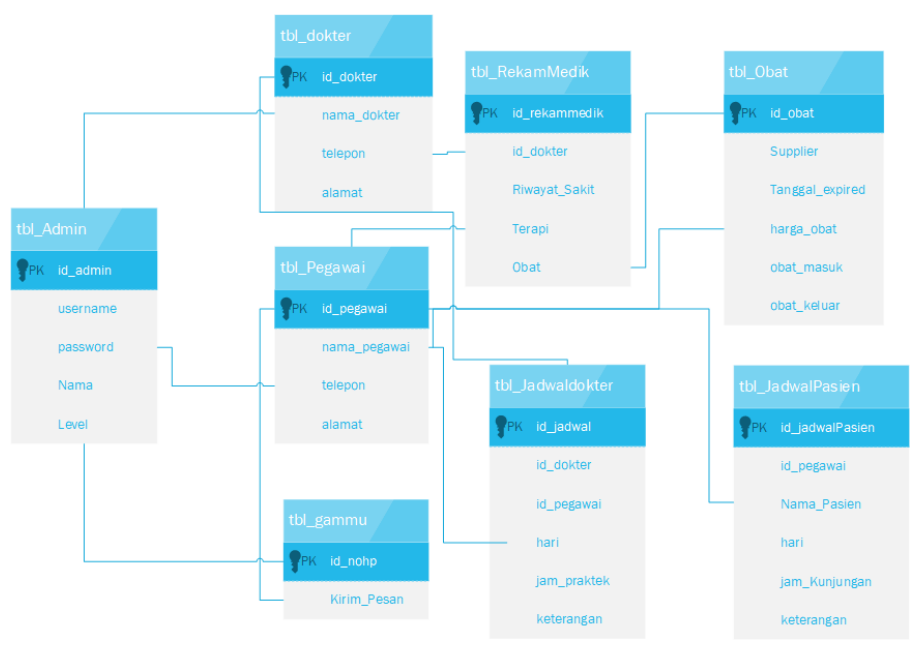

Figure 8. Logical Record Structure (LRS) Information System

\subsection{Construction}

The codes will be built to implement the results of the design in the previous phases based on the results of design. Then design of this information system will be formed into website with PHP programming language in CodeIgniter framework and MySQL database and uses Gammu as SMS Gateway. The display is friendly view to make the user easy to use, here is an example of the design of the display and report of the dental practice information system of Shahirah Rahmawati:

sisFo Praktek Dokter gigi Shahiriah Rahmawati

\section{Assalammualaikum}

Selamat datang di Sistem Informasi Praktek Dokter Gigi Shahirah Rahmawat.

Untuk menggunakan Sistem Informasi ini silakan login dahulu sesuai dengan TUPOKS.

Logan

Figure 8. Design of Home Display 


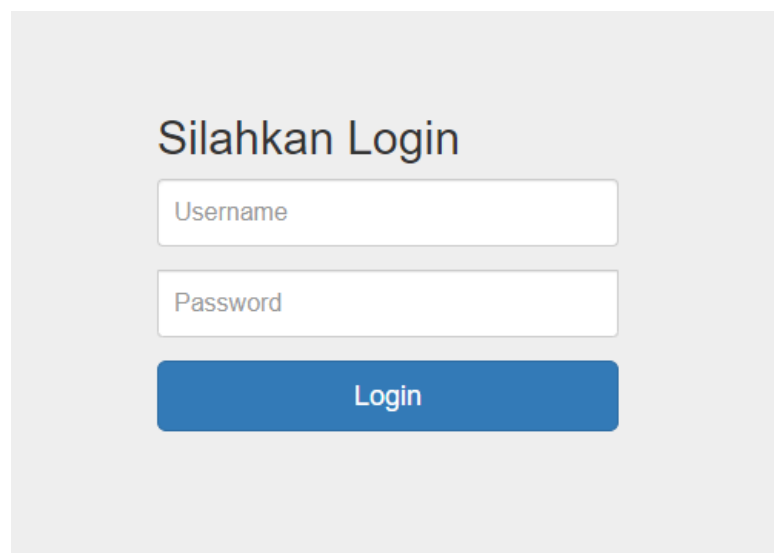

Figure 9. Design of Login

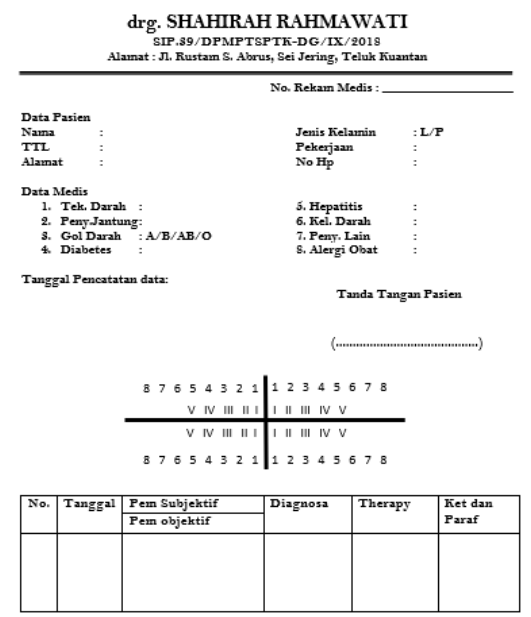

Figure 10. Design of Medical Record Report

\subsection{Transition}

In this phase, to know the fix application already to use will be conducted the experiment based on the needs in the early phase and the design, and will be conducted the introduction of the application to the user actors.

\section{Conclusion}

The conclusion was obtained in the process of planning and designing the application of the dental practice information system of Shahirah Rahmawati are as follows:

1. From the design of this system, it can answer the problems of manual management process and manual medical records in the dentist's practice.

2. From the design of this system use the RUP (Rational Unified Process) methodology, it can assist in the construction or implementation into codes (coding) same as the UML design.

3. Using the PHP Programming Language, Bootstrap and CodeIgniter Framework to design/manage the application interface and with the MySQL database as the DBMS for admin processing the application and classifying information system users easily. Then Gammu as a service to send SMS on the SISFO application based on SMS Gateway as media of information for patient return visits to the dentist's practice on scheduled.

\section{Acknowledgement}

Thanks to Shahirah Rahmawati Dental Practice, Teluk Kuantan on the opportunity was given in conducting the research based on the needs of the management of the dental practice, and also thanks to doctor and 
staff/employee for the answers from interviews and observation. And I do not forget to express my deepest thanks to the previous researchers.

\section{References}

[1] F. S. Noor, "Model Sistem Informasi Pada Praktek Dokter Gigi Berbasis Web,” pp. 1671-1680.

[2] M. H. Siregar, "Rancang Bangun Pengembangan Aplikasi Pemilihan Presiden Mahasiswa Melalui Sms Gateway," J. Teknol. Dan Open Source, vol. 2, no. 1, pp. 102-111, 2019, doi: 10.36378/jtos.v2i1.150.

[3] M. Destiningrum and Q. J. Adrian, "SISTEM INFORMASI PENJADWALAN DOKTER BERBASSIS WEB DENGAN MENGGUNAKAN FRAMEWORK CODEIGNITER ( STUDI KASUS : RUMAH SAKIT YUKUM MEDICAL CENTRE ),” vol. 11, no. 2, pp. 30-37, 2017.

[4] A. Nur Hidayat and E. Aribowo, "Sistem Informasi Manajemen Produksi Dan Penjualan Perusahaan Keramik (Study Kasus Keramik Mustika Banjarnegara),” JSTIE (Jurnal Sarj. Tek. Inform., vol. 3, no. 1, pp. 70-79, 2015, doi: 10.12928/jstie.v3i1.2924.

[5] K. Christianto et al., "Sistem Informasi Rekam Medis Kedokteran Gigi Berbasis Website," pp. 2-7.

[6] M. H. Siregar and N. W. Al Hafiz, "InfoTekJar : Jurnal Nasional Informatika dan Teknologi Jaringan Implementasi Aplikasi PEMIRA UNIKS Era Covid-19 Berbasis CodeIgniter dan SMS Gateway,” InfoTekJar J. Nas. Inform. dan Teknol. Jar., vol. 5, no. 2, pp. 105-109, 2021, doi: https://doi.org/10.30743/infotekjar.v5i2.3587.

[7] A. Hodijah, "PERANCANGAN MODEL PENGEMBANGAN PERANGKAT LUNAK BERBASIS SERVICE ORIENTED ARCHITECTURE MENGGUNAKAN METODOLOGI UNIFIED PROCESS,” pp. 253-261, 2017.

[8] S. Susilowati, "PERANCANGAN SISTEM INFORMASI PEMESANAN MAKAM BARU MENGGUNAKAN METODE RATIONAL UNIFIED PROCESS (Studi kasus pada Taman Pemakaman Umum Joglo Jakarta Barat)," J. Pilar Nusa Mandiri, vol. 13, no. ISSN 1978-1946 \& EISSN 2527-6514, pp. 92-97, 2017, [Online]. Available: http://ejournal.nusamandiri.ac.id/ejurnal/index.php/pilar/article/view/342.

[9] I. P. Sari and D. Arisandi, "Sistem Informasi Manajemen Klinik Gigi Berbasis Client Server (Studi Kasus Poliklinik Gigi Rsj Tampan, Pekanbaru)," Rabit J. Teknol. dan Sist. Inf. Univrab, vol. 2, no. 1, pp. 176-185, 2017.

[10] M. D. Cahyono, K. I. Satoto, and R. Kridalukmana, "Sistem Informasi Manajemen Pemesanan Dan Penjualan Pada UNDIP Distro,” J. Teknol. dan Sist. Komput., vol. 3, no. 3, p. 370, 2015, doi: 10.14710/jtsiskom.3.3.2015.370-378.

[11] A. R. N. Herlambang Ramadhani, “Aplikasi Web Pengiriman Dan Penerimaan Sms Dengan Gammu Sms Engine Berbasis Php,” JUMANTAKA, vol. 1, no. 1, pp. 191 - 200, 2018.

[12] A. Fadhola and H. Humisar, "Rancangan Bangun Sistem Informasi Administrasi," vol. 1, no. 5, pp. 436-441, 2018.

\section{AUTHOR(S) BIOGRAPHY}

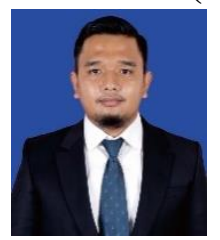

M.Hasim Siregar, S.Kom.,M.Kom, Dosen di bidang Jaringan Komputer dan RPL pada Program Studi Teknik Informatika Fakultas Teknik di Universitas Islam Kuantan Singingi RIAU dan beliau juga aktif sebagai instruktur pada pada cisco networking academy, oracle academy dan RedHat Academy di Universitas Islam Kuantan Singingi 